\title{
The Moral Irrelevance of Constitutive Luck
}

\author{
Mihailis E. Diamantis ${ }^{1}$ D
}

Received: 2 May 2020 / Accepted: 17 March 2021 / Published online: 2 July 2021

(C) The Author(s) 2021

\begin{abstract}
One's constitution - whether one is generous or miserly, temperate or intemperate, kind or mean, etc.- - is beyond one's control in significant respects. Yet one's constitution affects how one acts. And how one acts affects one's moral standing. The counterintuitive inference-the so-called problem of constitutive moral luck-is that one's moral standing is, to some significant extent, beyond one's control. This article grants the premises but resists the inference. It argues that one's constitution should have no net impact on one's moral standing. While a bad constitution lowers the chance that one will act morally, it offers significant gains to moral standing should that chance materialize. A good constitution increases one's chance of performing good acts but for correspondingly more modest gains. This effect should smooth out, and possibly eliminate, the expected impact of constitution on moral standing.
\end{abstract}

\section{Introduction}

Suppose you have to choose one of two games to play. In either game, you roll a die that has only one winning side. The games differ in the number of sides each die has and what you get if you win:

\begin{tabular}{lll}
\hline & Number of sides & Winning payout \\
\hline Game 1 & 6 & $\$ 6$ \\
Game 2 & 60 & $\$ 60$ \\
\hline
\end{tabular}

Which do you choose? If you do your math right, you should be indifferent. The expected payout is the same for both games: $\$ 1$. Though the chance of winning in Game 2 is lower, the higher potential payout balances those riskier prospects.

Now suppose that instead of choosing which game to play, you get to choose what sort of person you will be, i.e. what sort of constitution you will have. You need not

Mihailis E. Diamantis

mihailis-diamantis@uiowa.edu

1 College of Law and Department of Philosophy, University of Iowa, Boyd Law Building, rm.

442, Iowa City, IA 52242, USA 
imagine that you are engaging in some act of "magical ex nihilo [self-]creation." (Feinberg 1986, p. 34). You retain at least the rudiment of your present makeup, but you can choose to alter some constitutional trait. You could choose to be temperate or intemperate, empathetic or egocentric, prone to honesty or dissimulation, etc. Your choice of trait will affect how easily choosing to do the right thing comes to you. If you are concerned with your moral standing, the choice may seem obvious. Should you not clearly choose to be temperate rather than intemperate? After doing so, you will be more inclined to act rightly ${ }^{1}$ when opportunities for intemperance present themselves, thereby increasing the likelihood that you will act rightly and improve your moral standing.

For better or worse, we do not have complete control over our constitutiongenetics, upbringing, and other life experiences play a formative role. To the extent we can influence our constitution, we do not start with a blank slate. (Strawson 1994). Since there are seemingly better and worse alternatives when it comes to constitution, traits we would have chosen or avoided were that possible, we may feel morally lucky or unlucky as we find ourselves with constitutions that incline us to act rightly or wrongly. Many philosophers believe it is deeply troubling that luck can impact moral standing in this way.

This article argues that the overall moral effects of constitutive luck are less significant than previously supposed (the "Weak Thesis") or possibly even non-existent (the "Strong Thesis"). The argument that constitutive luck is morally problematic moves from three premises-luck affects constitution, constitution affects action, and action affects moral standing - to the conclusion that luck affects moral standing. But that inference ignores the possibility of interaction effects between action and constitution that impact how action influences moral standing. For example, as suggested below, there could be an inverse relationship between the moral worth of an act and the strength of one's constitutional inclination to perform it. While a person may be less likely to do the right thing if she is constitutionally disinclined, the potential improvement to moral standing should she succeed could be higher. Conversely, to the extent a person is constitutionally more inclined (and so more likely) to act rightly, the gain to her moral standing could be smaller when she so acts. The expected effect on moral standing of having a good or a bad constitution could even out. If one's constitution is a matter of relative indifference so far as one's moral standing is concerned, constitutive moral luck becomes less worrisome. It may even disappear altogether.

The article starts with some important clarifying preliminaries (Part 2) and assumptions (Part 3). It then moves on to the argument (Part 4) and responds to objections (Part 5). It concludes with a short summary (Part 6).

\footnotetext{
${ }_{1}$ I frame the argument below in terms of right and wrong action. I could reframe the argument in terms of choices to perform right or wrong action for readers who find that formulation of the problem of constitutive moral luck more intuitive.
} 


\section{Setup}

"Moral luck," which a pair of articles by Tom Nagel and Bernard Williams brought to salience, refers to situations where something beyond one's control affects one's moral standing. (Nagel 1976; Williams 1976). For present purposes, "moral standing" refers to objective praiseworthiness and blameworthiness. ${ }^{2}$ Its existence is widely considered problematic since it seems to conflict with the intuition that one's moral standing must be entirely under one's control. (Nelkin 2013; Strawson 1986). As others have argued, that intuition needs some refinement since there are factors beyond one's control that affect moral standing in unproblematic ways. For example, "we are remarkably lucky to be agents at all;" a lightning bolt or tragic disease could put an end to any of us at any moment, taking our moral standing along with it. (Fischer 2006, p. 113). This sort of luck, which pertains to whether one has moral standing at all, does not seem intuitively problematic. Problems of moral luck are not about luck in whether one has moral standing. They presume one has it. Rather, they are about the role of luck in how the moral standing one does have turns out. To borrow an analogy: There is no problem simply because "we can be accountable for playing the cards that are dealt us, even if we did not manufacture the cards, write the rules of the game, and so forth." (Ibid., p. 129). The problematic luck enters the picture when we realize that the cards are stacked against some of us: some of us have five aces, and some of us only have one.

Four varieties of moral luck are commonly distinguished: "Resultant luck" is luck in whether the consequences of one's actions turn out good or bad. "Circumstantial luck" is luck in the kinds of problems and situations one faces, whether they offer opportunities for right or wrong action, and in which direction they push. "Constitutive luck" (the focus of this article) is luck in "the kind of person you are, where this is not just a question of what you deliberately do, but your inclinations, capacities, and temperament." (Nagel 1976, p. 140). Lastly, "causal luck" refers to luck in whether the external causal determinants of one's will (assuming those exist) lead one to act rightly or wrongly.

Setting aside the deep and enduring controversies over free will that causal luck raises, constitutive moral luck has proved particularly intractable. (Enoch \& Marmor 2007; Hartman 2017; Latus 2003). Constitutive luck strikes uncomfortably close to our understanding of ourselves as moral agents. (Andre 1983; Statman 1997). Resultant and circumstantial luck allow us to preserve the sense that, even if our moral projects fail, we may still be good people situated in an unfortunate world.

\footnotetext{
2 There is some ambiguity in the moral luck literature about what exactly it is that luck problematically influences. In his foundational article, Nagel vacillates between "moral judgment," "moral assessment," "blame," "natural objects of moral assessment," "responsibility," and "culpability." (Nagel 1976). Nagel is also often unclear about whether he means these in objective or sociological senses (i.e. how much blame one deserves, or how much blame one actually receives from one's peers). Many other philosophers working on moral luck have inherited the ambiguity. I believe that the problem of moral luck is most intractable if its problematic object is taken to be one's objective moral standing: how well, morally speaking, one is objectively doing. I am not alone in resolving the ambiguity this way. (Rescher 1993; Strawson 1994; Zimmerman 2002).
} 
(Thomson 1989; Zimmerman 2002). Constitutive luck threatens to undermine the comfort we can take even in being good. The humbling reminder, "There but for the grace of God go I," becomes more humbling still if applied not only to where I find myself but also to who I find myself to be. (Schinkel 2009).

I should pause for a moment to clarify what I mean by "constitution." One's constitution is the sum of one's constitutional traits. Nagel understood constitutional traits to include such things as personal "inclinations" and "temperament[s]." (Nagel 1976, p. 140). More generally, he defined traits of constitution to be tendencies to behave in particular ways "under the influence of... certain feelings under certain circumstances and... strong spontaneous impulses to act." (Ibid., p. 144-145). I will follow his lead here. ${ }^{3}$ Constitutional traits may be part of one's genetic inheritance, but they may also arise or change later in life, as a product of upbringing or even purposeful cultivation. I hope to side-step the thorny question of how to individuate constitutional traits since it should not impact the argument below. What is important is that traits (however individuated) impact inclination and behavior. Subject to that caveat, I accept as paradigmatic the sorts of constitutional traits mentioned by Nagel: greed, cowardice, generosity, kindness, and vanity. A person has the constitutional trait of kindness to the extent that her feelings, impulses, and tendencies incline her to do kind things.

The problem of constitutive moral luck only arises to the extent that one's constitutional traits are beyond one's control. I assume that there are limits to the control we (or at least some of us) have over (at least some of) our constitutional traits. It may be that some of people are born with unshakeable inclinations or stubbornly fixed temperaments. Or it may be that natural inclinations and temperaments serve as anchors, constraining what further inclinations and temperaments are reachable through purposeful cultivation. For the sake of concreteness, when I refer to constitutional traits below, I mean natural constitutional traits that are fixed at birth and which one cannot alter through any exercise of control. If these exist, they pose the problem of constitutive moral luck in its starkest terms. Even if they do not exist, a solution to the problem they would pose will offer a template for solving the problem as it arises with respect to different and perhaps less determinate vectors of external influence over one's constitution.

The argument below is offered primarily on behalf of deontologists. There is reason to think that constitutive moral luck, if it exists, poses the most significant challenge to deontological theories. ${ }^{4}$ This is because of the crucial role that control plays

\footnotetext{
3 I think this preferable to following William's characterization of constitutional traits as "dispositions" to behave one way or another. (Williams 1976). In the Aristotelian tradition that "disposition" invokes, dispositions may be purposely cultivated. (Aristotle (Ross \& Brown trans.) 2009). This puts dispositions under one's control, even though natural inclinations and tendencies may influence the extent of one's control. It is possible to frame the problem of constitutive moral luck using a dispositional understanding of constitutional traits, but it would circle once again back to things like Nagel's inclinations and tendencies. I think it cleaner to focus on these from the outset.

4 This is not to say that all deontologists must concede that constitutive moral luck exists. They may reject any of the premises that lead to the problem by denying that factors beyond one's control can impact one's constitution or denying, to the extent such factors can impact constitution, that constitution problematically impacts behavior. (Baxley 2010, ch. 2). The Kantian distinction between Sinnesart and Denkungsart could be a helpful resource in this regard. (Frierson 2017). This article is primarily for
} 
in making moral luck problematic. Constitutive moral luck loses its bite without the intuition that one's moral standing must be within one's control. Control has a salience across deontological theories that it lacks for many consequentialists and virtue ethicists. One's good will, which for many deontologists should "like a jewel ... shine by itself," is tied up with one's moral standing precisely because of and to the extent of one's control over it. (Kant (Gregor trans.) 1785, Ak. 4:394). If one's will is significantly influenced by factors beyond one's control (e.g. one's constitution), its availability for deontologists as the key measure of one's moral standing becomes suspect.

This chain of reasoning would not resonate with many consequentialists and virtue ethicists. While virtue ethicists may debate the extent to which one's character is under one's control, they historically have recognized the significant influence of luck (e.g. in one's birth or upbringing). ${ }^{5}$ (Aristotle (Ross \& Brown trans.) 2009; Nussbaum 1986; Slote 1992; Leunissen 2017). Williams himself alluded to this ancient line of thought: "[W]hile the good man, the sage, was immune to the impact of [resultant] luck, it was a matter of what may be called constitutive luck that one was a sage, or capable of becoming one." (Williams 1976). Consequentialists, who have played a more modest role in the debate over moral luck, often have a similarly ambiguous relationship with control. They care foremost about maximizing good consequences, often heedless of whether the process by which that happens is under one's control. ${ }^{6}$ (Statman 1997).

\section{Three Further Premises}

I aim to show that deontologists have resources to mitigate or eliminate the concerns posed by constitutive moral luck, even granting the premises that are said to lead to the problem. Consequently, I will assume that one's acts affect one's moral standing, one's constitution affects how one acts, and factors beyond one's control affect one's constitution. I also accept the deontological intuition that one's moral standing is under one's control. As such, the argument that follows is different from most attempts to answer problems of moral luck since it neither questions the role of luck nor the moral significance of control.

\footnotetext{
Footnote 4 (continued)

deontologists who do worry that constitutive moral luck exists. I do not undertake the burden of arguing for the premises that are said to generate the problem of constitutive moral luck. I assume the truth of those premises and argue against the inference from them to a problem.

5 Aristotle does point out that we do not blame people for character traits they had no power to change: "Of vices of the body, then, those in our own power are blamed, those not in our power are not. And if this be so, in the other cases also the vices that are blamed must be in our own power." (Aristotle (Ross \& Brown trans.) 2009, 1114a). I read this as a sociological observation. Aristotle is clear that a trait of character is virtuous only insofar as it is conducive to eudaimonia. A vice is no more conducive to eudaimonia if at arises unchangeably from birth than if it arises from poor habit later in life.

6 Mill (1863) remarked that one's intention, while having no relation to the rightness of one's acts, may have a bearing on one's "worth." Reconciling this position with the broader themes of utilitarianism has vexed commentators. (Dancy 2000).
} 
I need three further premises (beyond those that generate the problem of constitutive moral luck in the first place) to get the argument going. Though the argument that follows focuses on the impact that acting rightly has on moral standing, analogous points (suitably inverted) would apply for acting wrongly.

\subsection{The First Premise}

The first premise is a definition of luck. A state of affairs can only be said to be lucky if it is one among multiple possible states of affairs, one lacks control over whether it obtains, and one has reason to prefer it over the other possible states of affairs. (Hartman 2017; Rescher 1993, 1995). "The core concept of luck is the idea of things going well or ill for us due to conditions and circumstances that lie... beyond our cognitive or manipulative control."7 (Rescher 1990, p. 7). In the six-sided die game described at the start of this article, the possible states of affairs include throwing a winning roll or throwing a losing roll. One has little control over how the roll turns out, yet one has reason to prefer the winning roll. How the roll turns out is therefore a matter of luck. Suppose instead, though, that one must first toss a coin to determine whether one will play the six-sided or sixty-sided game. One has little control over how the toss turns out, but luck is not in play because one has no reason to prefer playing one game or the other. The expected payout of the two games is the same. Of course, one would prefer to win $\$ 60$ rather than $\$ 6$, but the coin toss would determine the game, not whether one will then go on to win.

Some have argued that the notion of luck in one's constitution is incoherent. (Hurley 1993; Rescher 1990, 1993). While these critics may grant that there are better or worse constitutional traits to have, they deny that it is coherent to speak of alternate possible states of affairs in which the same person is very differently constituted. There are two responses available. One is specific to the dialectical posture of this article. I am not arguing that there is a problem of moral luck. Rather, I assume that the premises that some people think lead to the problem of constitutive moral luck are true. I am arguing against the inference from those premises to the purported problem.

The second response to the those who are skeptical of luck in constitution is more substantive. Recall that constitutional traits are inclinations, tendencies, and temperaments that incline one to behave in particular ways. The sum total of these may be essential to who one is. For some people, there may even be isolated constitutional traits that are essential to who they are. It may be incoherent to speak of luck with respect to these constitutional traits or with respect to the sum total of one's constitutional traits. However, with respect to the rest, I am persuaded by the reply that asking about non-essential constitutive traits one-by-one-e.g. would you choose to be more courageous than you are-avoids the concern. (Latus 2003). If I am unkind,

\footnotetext{
7 The ellipses here elide the word "wholly." In the same paper from which the quote is drawn, Rescher acknowledges that an event need not be wholly beyond our control for luck to be involved. To borrow an example from him - the person who purchases a lottery ticket thereby increases her chances of winning, though she is still lucky if she does win.
} 
but not essentially so, I can coherently entertain possible states in which I am kinder. It is on this basis that I can, without risking incoherence, wish I were kinder, or even aspire to become kinder.

\subsection{The Second Premise}

The second premise I need is that one's constitutional traits increase the likelihood that one will act in accordance with them, but they do not necessitate that one will so act. A person who is unkind has feelings and impulses that, by inclining her to perform unkind acts, increase the likelihood that she will act unkindly. (Enoch \& Marmor 2007). Yet she may still, on any occasion, choose to do something kind. ${ }^{8}$ As Galen Strawson (1994, p. 20) would describe this premise (and then criticize it), “one's self is, in a crucial sense, independent of one's character or personality or motivational structure." This is a common understanding of the relationship between constitution and action: "Such qualities as sympathy or coldness... provide the background against which obedience to moral requirements is more or less difficult." (Nagel 1976, p. 144). As such, acting rightly "may be easier for some than for others, but it must be possible to [act rightly] by making the right choices, against whatever temperamental background." (Ibid., p. 145).

Though this second premise is well-situated within the literature on constitutive moral luck, it could do with some clarification. Since the premise is about the relationship between constitution and will, at issue is the line between constitutive moral luck (the present topic) and causal luck (luck in the causal determinants of one's will). I have said that constitutional traits are such things as inclinations, temperaments, and impulses. In common experience, these all come in degrees of strength. At one extreme, they can be trivial inner proddings that are easily dismissed as one chooses what to do. At the other extreme, they can exercise an iron grip over the will by raising some possible courses of action to undismissible salience: inclination bleeds into obsession, temperament shades into compulsion, and impulse becomes irresistible. Obsession, compulsion, and irresistible impulses are matters of causal luck because they determine what one will do. Constitutive luck, by definition, is about traits that fall short of this extreme. They exert pressure on one's will, but do not determine it.

Attributes that might go under the headings "strength of character" or "willpower" could also straddle the line between causal and constitutive luck. ${ }^{9}$ A student who routinely finds herself drinking and playing videogames on Wednesday night rather than studying (perhaps despite realizing that studying is all things considered

\footnotetext{
8 Without this limitation, the discussion would shift from constitutive luck to causal luck, i.e. luck in the determinants of one's will. Of course, an unkind person cannot behave kindly too often without calling into question whether she is really unkind. What counts as "too often" is a familiar problem in character theory that I set aside.

9 The contents of this paragraph are highly tentative. I am personally unresolved as to the coherence of talking about degrees of willpower or strengths of will. However, I concede that it is a common way of speaking and endeavor here to discuss willpower solely for the purpose of clarifying what constitutive traits are.
} 
preferable) may be said to "lack willpower." If the student drinks and plays videogames just because she has strong (but ultimately resistible) inclinations to do so, then these are garden variety constitutional traits. Suppose instead that her will is weak in a way impacts the effort she can or does exercise to overcome her inclinations. Perhaps there are upper bounds to the effort of will she can exert so that inclinations of lower intensity (inclinations that other agents could overcome) end up determining her will. Or perhaps she can exert her will less frequently than other people, so that she must "choose her battles" and lose against wayward inclinations once her willpower is expended. These scenarios raise issues of causal rather than constitutive luck because they have outcome determinative force over what the student does. An irresistible inclination determines one's will, regardless of the reason for it being irresistible. Similarly, a limit on the reserve of will one has to expend in overcoming inclinations determines how often one can succeed (i.e. how many functionally irresistible inclinations one will encounter) even if it does not antecedently fix to which inclinations one will succumb.

One might worry that the premise presently under discussion conflicts with one of the initial premises needed for generating the problem of constitutive moral luck. If "it must be possible to [act rightly] by making the right choices, against whatever temperamental background," does constitution still affect action in problematic ways? Nagel certainly thought so because he accepted both premises. Even if a constitutional trait does not determine what one will do in any given instance, it must prod one to act in accordance with it. It would be hard to make sense of inclinations, tendencies, and impulses that never affected how one acts. Even if constitution never determines individual actions, luck in constitution will still seem morally problematic since its effects will be apparent across sets of actions. Playing chess without my queen does not necessitate that I will lose, but if I aim to win, it is preferable to start with all my pieces. Analogously, a constitution that inclines toward, rather than away from, right action may still seem morally preferable.

\subsection{The Third Premise}

The third premise is that the gains to one's moral standing from acting rightly are smaller if one's constitution already disposes one so to act, and they are greater if one's constitution disposes one against so acting. ${ }^{10}$ Kant controversially articulated a position in the vicinity of this premise when he described examples of people who overcome contrary inclination to act from the motive of duty. For example:

[I]f nature had put little sympathy in the heart of this or that man; if (in other respects an honest man) he is by temperament cold and indifferent to the sufferings of others ... would he not still find within himself a source from which

\footnotetext{
10 Roger Crisp (2017) briefly makes an analogous observation in the context of circumstantial moral luck: "A harder choice may be more praiseworthy, so to this extent the circumstantial bad moral luck of the man who stayed in Germany was counterbalanced by the greater moral opportunities available to him. And as it becomes more difficult to make the correct choice, so it becomes a lesser wrong not to make it."
} 
to give himself a far higher worth than what a mere good-natured temperament might have? By all means! It is just then that the worth of character comes out, which is moral and incomparably the highest, namely that he is beneficent not from inclination but from duty. (Kant (Gregor trans.) 1785, Ak. 4:398-399).

Kant's discussion is controversial (Benson 1987; Stocker 1976), as is exegesis of it. Some interpreters read Kant in a way that is broadly sympathetic to my third premise, so that inclinations that favor right action are an impediment to realizing moral worth. (Henson 1979). Others disagree. (Herman 1981).

Regardless of Kant exegesis, ${ }^{11}$ the third premise has its own intuitive appeal. In non-moral domains, we commonly recognize the superior value of a victory won through struggle or adversity in comparison to a victory that comes easy. We cheer louder for the athlete who wins through hard training than we do for the athlete whose natural gifts carry her over the finish line. We cheer louder still for the athlete who overcomes unusual setbacks - an illness or a disability - to succeed. We recognize the superior achievement of the self-made millionaire over that of the heiress.

This pattern carries over to the domain of moral assessment. (Nelkin 2016). We often feel that the person who struggles against her constitution to do the right thing has accomplished a greater moral victory when she succeeds than the person who casually does the right thing from natural inclination. The point is best made by illustration, and examples abound. Consider Neville Longbottom, a young wizard from the Harry Potter books. Precisely because the books introduce him as timid and soft-spoken, we celebrate (and the Hogwarts School of Wizardry administrators award) his isolated acts of courage, e.g. standing up to his friends. Contrast that with Harry Potter's continuous string of courageous acts-from joining Hogwarts as an outsider to outrunning dementors-all of which heighten our sense of adventure but few of which distinctly increase our esteem. For a more classic example, consider Magwich, the violent felon in Dickens' Great Expectations who, after escaping prison, secretly devotes his life to helping a young orphan he chances to meet. Of the many selfless benefactors throughout Dickens' novels, Magwich's actions stand out as morally transformative because of the thieving and murderously self-centered constitution we know him to have.

This third premise may seem to conflict with the intuition some have about the exceptional moral standing of an individual who, through an arduous journey of self-development, manages to cultivate inclinations and dispositions to act rightly. Insofar as the argument here is presented on behalf of deontologists and not virtue ethicists, this Aristotelian intuition will resonate less forcefully with my intended audience. (Nelkin 2016). Even so, the tension between the third premise and this Aristotelian intuition is not so great as it may at first seem. Consider by way of illustration an individual who begins with a bad constitution, but who through effort and repetition, manages to habituate herself to act rightly and thereby acquire a better

\footnotetext{
11 Indeed, even the most favorable interpretation of Kant's position would conflict with my third premise. He states that there is no moral worth in acting rightly from inclination rather than from moral duty. As will become clearer later, my third premise necessitates that one who acts rightly from inclination still accrues some (albeit relatively small) gain to moral standing.
} 
constitution. Such an individual is, according to the Aristotelian intuition, doing very well, morally speaking. The result is no different according to the third premise. By continuously overcoming her bad inclinations in order to act rightly, the individual is also doing very well morally speaking from this deontological perspective. The difference between the two ways of accounting for moral worth is more a matter of timing than a matter of total assessment. Under the Aristotelian intuition, moral standing increases as the individual comes closer to cultivating the right dispositions. According the third premise advocated here, the steepest gains to moral standing come early on, when the individual acts rightly and contrary to inclination.

One can grant this third premise - that the positive contribution to a person's moral standing from acting rightly is inversely related to the strength of her inclination so to act-without committing to any precise view on what ratio relates one's constitution to an act's contribution to one's moral worth. My argument for the Strong Thesis - that constitutive luck is morally irrelevant-requires that the ratio be the exact inverse proportion (the "Inverse-Proportion Assumption"). For example, a person whose inclination to act rightly is twice as strong as another's would gain half as much as the other in moral standing for performing the same right act. If the ratio were ever so lightly more or less than an exact inverse proportion, there would be space for problematic constitutive moral luck to rearise.

The exactitude of the Inverse-Proportion Assumption is very demanding and will likely raise eyebrows. It seems too precise, too convenient... too good to be true. Still, there are three points to be made in its favor. Admittedly, none is dispositive. However, together, they might make the Assumption seem marginally less fantastical than the alternatives.

Though this first point smacks of bootstrapping, it is no small consideration that (as I argue below) the Inverse-Proportion Assumption permits an appealing solution to the problem of constitutive moral luck. The solution is appealing among alternative approaches because it preserves uncompromised all the basic intuitions that are said to lead to the problem-that one's constitution is (to an extent) out of one's control, that constitution affects action, that action affects moral standing, and that one's moral standing is under one's control. Other approaches might ultimately reject (or attempt to explain away) one of these basic intuitions, or embrace incoherence in our moral commitments (Nagel 1976), or lead to responsibility skepticism (Strawson 1994). Before rejecting the Inverse-Proportion Assumption, we should reckon with what hangs in the balance, because something else would have to give way: our belief that we are morally responsible agents, the coherence of our basic moral commitments, or the truth of the three premises that generate the problem of constitutive moral luck. The costs of rejection can make the Inverse-Proportion Assumption an easier pill to swallow.

Second, I believe that part of what makes the Inverse-Proportion Assumption feel farfetched has less to do with the mathematical relation it posits and more to do with our discomfort when talking about constitution and moral standing in mathematical terms. In other nearby value-laden domains where numbers are more familiar, analogues of the Inverse-Proportion Assumption are much easier to digest. The parable of the Widow's Mite (Mark 12:41-44) makes sense because we perceive there to be some sort of inverse relationship between the amount of alms one should (in a religio-moral 
sense) give and the personal burden that each unit of currency represents to the giver. For the widow, each mite represents a large personal burden, yet her two mites are more significant (again, in a religio-moral sense) than the much greater sums that the rich people in the parable contribute. Suppose that donating a single mite entails only $1 / 10,000$ th of the personal burden for a rich person as it does for the widow. How much must the rich person give in order to realize the same religio-moral significance as the widow's two? While there are multiple of plausible answers, it would not overly strain credulity to propose an exact inversely proportional measure. The rich person would have to donate exactly 20,000 mites to realize the same religio-moral significance. And a slightly richer person for whom donating a single mite is only $1 / 11,000$ th as burdensome as for the widow would have to donate 22,000 mites.

We have no established currency for moral standing or constitutional traits, and so talking about precise numerical relationships between them can feel alien or uncouth. It may engender the sort of skepticism that Robert Hartman (2019, p. 3190) recently expressed: "I am dubious that weighting difficulty in proportion to degrees of praiseworthiness and blameworthiness could ever be precise enough to grant everyone equal moral opportunities." Two observations may help stave off doubt. First, in order to accept the Inverse-Proportion Assumption, we do not need to be able to weigh precise degrees of moral standing or strengths of constitution. We do not even need to articulate suitable units for measurement. The Inverse-Proportion Assumption may be true and we may have reason to believe it even if we lack the moral technology to test it. Second, posing a problem of constitutive moral luck but then objecting to the InverseProportion Assumption solely because of its mathematical orientation risks setting different standards for problem and solution. Setting up the problem of constitutive moral luck requires comparing strength of constitution and moral standing between different people. If measurement and basic arithmetic can motivate the problem, they should be available to solve it as well.

Lastly, however farfetched the Inverse-Proportion Assumption may seem, the alternatives - once articulated in mathematical terms-will seem at least as farfetched. If the ratio is not an exact inverse proportion, what is it? Does moral standing from right action increase in inverse proportion to the square of the strength of constitutional traits favoring it? Is the relationship inversely proportional to 1.2 times the strength of one's constitution? Or inversely proportional but with a kicker of +5.3 ? None of these sounds particularly appealing. While absence of a reason to believe an alternative is not a dispositive reason to concede the Inverse-Proportion Assumption, it does lower the theoretical costs of concession.

If the Inverse-Proportion Assumption is false - the ratio is inverse but not exactly inversely proportional - then my ambitions in this article must be correspondingly moderated. Constitutive luck would still be morally relevant, but less relevant than typically supposed. This is the Weak Thesis, which I discuss further in part 5. 


\section{The Argument}

Now the argument against constitutive moral luck should be easy to anticipate. If luck were relevant to constitution, then there should be some agent $\mathrm{A}$ who has reason to prefer (if she had the choice) some constitutional trait X over another constitutional trait Y. Since the luck in question is specifically moral, the reason should relate to A's concern for her moral standing. That is to say, there should be some time where A could expect that, with $\mathrm{X}$, she would be more likely by some factor, F, to take some right action $\mathrm{R}$ than if she had $\mathrm{Y}$. Let the probability that A would do $\mathrm{R}$ if she had $\mathrm{Y}$ be $\mathrm{p}(\mathrm{Y})$. Then $\mathrm{p}(\mathrm{X})$, the probability that $\mathrm{A}$ would do $\mathrm{R}$ if she had $\mathrm{X}$, is equal to $\mathrm{F} \cdot \mathrm{p}(\mathrm{Y})$. Let $\mathrm{m}(\mathrm{X})$ and $\mathrm{m}(\mathrm{Y})$ be the gain to moral standing A would realize for doing $\mathrm{R}$ with $\mathrm{X}$ and $\mathrm{Y}$, respectively. Then, according to basic probability theory, $\mathrm{p}(\mathrm{X}) \cdot \mathrm{m}(\mathrm{X})$ is A's expected gain in moral standing from having $\mathrm{X}$ (at least so far as $\mathrm{R}$ is concerned). Similarly, her expected gain from having $\mathrm{Y}$ is $\mathrm{p}(\mathrm{Y}) \cdot \mathrm{m}(\mathrm{Y})$. Since A's increased moral standing from doing $\mathrm{R}$ is inversely proportional to the strength of the inclination she has to do $\mathrm{R}, \mathrm{m}(\mathrm{X})=\mathrm{m}(\mathrm{Y}) / \mathrm{F}$. The net improvement in moral standing A should expect from having $\mathrm{X}$ rather than $\mathrm{Y}$ is:

$$
(\mathrm{p}(\mathrm{X}) \cdot \mathrm{m}(\mathrm{X}))-(\mathrm{p}(\mathrm{Y}) \cdot \mathrm{m}(\mathrm{Y}))
$$

Substituting for $\mathrm{m}(\mathrm{X})$, we have:

$$
(\mathrm{p}(\mathrm{X}) \cdot(\mathrm{m}(\mathrm{Y}) / \mathrm{F}))-(\mathrm{p}(\mathrm{Y}) \cdot \mathrm{m}(\mathrm{Y})) .
$$

Substituting for $\mathrm{p}(\mathrm{X})$, we have:

$$
\begin{aligned}
& ((\mathrm{F} \cdot \mathrm{p}(Y)) \cdot(\mathrm{m}(\mathrm{Y}) / \mathrm{F}))-(\mathrm{p}(\mathrm{Y}) \cdot \mathrm{m}(\mathrm{Y})) \\
= & ((\mathrm{F} \cdot 1 / \mathrm{F}) \cdot \mathrm{p}(\mathrm{Y}) \cdot \mathrm{m}(\mathrm{Y}))-(\mathrm{p}(\mathrm{Y}) \cdot \mathrm{m}(\mathrm{Y})) \\
= & (\mathrm{p}(\mathrm{Y}) \cdot \mathrm{m}(\mathrm{Y}))-(\mathrm{p}(\mathrm{Y}) \cdot \mathrm{m}(\mathrm{Y})) \\
= & 0 .
\end{aligned}
$$

It follows that agent A could expect no greater gain in moral standing by having trait $\mathrm{X}$ rather than trait $\mathrm{Y}$ with respect to act $\mathrm{R}$. Since $\mathrm{A}, \mathrm{X}, \mathrm{Y}$, and $\mathrm{R}$ were arbitrary, no agent can expect any trait ever to be better for her moral standing than a competing trait. This means there can be no reason (so far as one's moral standing is concerned) to prefer one trait over another. In other words, assuming the premises set out above are correct, constitutive luck is morally irrelevant.

\section{Some Objections}

Even if one accepts the premises of the foregoing argument, aspects of it may raise concern. For example, I frame the argument in game-theoretic terms from the perspective of someone concerned to maximize her moral-standing. I agree that this way of speaking and thinking about moral matters is generally objectionable. (Smith 1994). I do not mean to propose game theory for general use in moral discourse and 
thinking. For limited purposes, game theory can offer a model to facilitate a more precise discussion that would otherwise be more cumbersome and less precise. ${ }^{12}$

Once game theory and preferences come into the picture, I should have something to say about risk preference and aversion. As between the two dice games mentioned at the start of this paper, people concerned solely about expected payout should be indifferent. But most people also have preferences for higher or lower levels of risk. A risk averse person would opt for the six-sided game, while a risk preferring person would opt for the sixty-sided game, even though the expected payouts are the same. Could there be a similar phenomenon when it comes to moral risk? For example, would a risk preferring person consider herself unlucky to have a constitution that disposes her to act rightly for lower gains to moral standing? There are two possible responses. One is to just ask incredulously, "Risk preference in moral standing?! Even if it does exist, can it really be the sort of thing that can counts as a moral reason for the preference?" The other response is to concede the possibility and acknowledge that with it a sort of constitutive luck rearises. But it would be less threatening than the kind of constitutive luck that worried Nagel and Williams. After all, this sort of luck still has no net expected impact on one's moral standing. The loss or gain is only to whatever (dis)value one attaches to risk.

Relatedly, even if I am right that, so far as one's moral standing is concerned, one should be indifferent between good and bad constitutional traits, there are still very good reasons for one to prefer having good traits. After all, one's traits affect how one will treat others, and having bad traits increases the likelihood that one will mistreat others. There is something off about a person who would be indifferent to that fact, even if she stands to gain much in personal moral standing when she overcomes her bad inclinations. This means there is a reason to prefer having good traits. However, this is not the sort of reason that suffices to show that one is morally lucky or unlucky. The reason at issue is fully other regarding. Those with whom one deals — one's friends, acquaintances, family, colleagues — may be more or less lucky depending on how one's constitution impacts them. If the argument offered above is right, one can have no claim to one's own good or bad moral luck by virtue of one's constitution. While a person should choose a good constitution (if she can), she is not morally unlucky if the fates give her a bad constitution.

Perhaps more worrying is the fact that people with worse constitutions can expect to be blamed, condemned, and punished more than people with better constitutions. Not only will they commit bad acts more often (and be blamed for them), but they are also less likely to be highly praised and celebrated when they overcome their bad constitutions to do something right. This is indeed a kind of constitutive luck - things tend to go better for people who have better constitutions. But, again, it is not a species of moral luck. It is true that our actual practices of praise and blame do not track objective moral standing. This is in significant part because the things people can observe about each otheracts in circumstances and results therefrom-are unreliably correlated to moral

\footnotetext{
${ }^{12}$ I am not alone in speaking of in numerical terms. Zimmerman (2002, p. 555) talks about “'entr[ies]' in one's 'moral ledger."'.
} 
standing. (Thomson 1989; Zimmerman 2002). The examples of Neville Longbottom and Magwich from above generate the right responses in us because, through the literary magic of fictional narrative, we have a transparent window into their constitutions. In the real world, as Norvin Rescher (1993, p. 199) describes it, a person "may be lucky or unlucky in how clear his deserts are" to others. One may be lucky or unlucky in that others may blame one less or more severely than one deserves, but that does not affect the objective moral facts about one's true (but misapprehended) moral standing.

Finally, what if we cannot swallow the precision required of the InverseProportion Assumption? Is the entire article for naught? In that case, my argument for the Strong Thesis would not work. The series of equations would not zero out. But I would still have made headway against the problem of constitutive moral luck, or, at least, how much the problem should worry us. If the inverse relationship between the gains to moral standing from right action and the strength of constitutional traits favoring it is not an exact inverse proportion, we should expect constitutional traits to produce some difference in moral standing. But those differences would be smaller than we might have feared were it not for the interaction effects between constitution and gains to moral standing that I discuss.

We might also worry less about constitutive moral luck if the Weak Thesis is true because, after rejecting the Inverse-Proportion Assumption, we may lose our grip on whether particular constitutional traits make us lucky or unlucky. For those of us with worse constitutions, a rejection of the Inverse-Proportion Assumption might mean that we should expect to be morally worse off: the increased gains to moral standing we realize from right action will sometimes be inadequate to make up for net the burden of our bad constitution. If I am half as likely to be kind, maybe I get less than double the gain to moral standing when I act kindly. However, for all we know after rejecting the Inverse-Proportion Assumption, a bad constitution might end up being a moral windfall. Maybe there are expected net gains to moral standing from having a bad constitution, so that I get more than double the gain to moral standing for acting kindly if my constitution makes me half as likely to be kind.

This would mean that there is constitutive moral luck, but we may no longer be sure about how lucky good constitutions are or how unlucky bad ones are. Some insight from a philosopher who is abler than I might tip the epistemic scales, but, for now, we might get a temporary reprieve from worry. Return to the dicing example with which this article opened. You should be indifferent between the two dice games because you know they have the same expected payout. But what if you are told to pick between two games and are given no information about the odds and payouts of either? There may be a better and a worse choice, but from your position you cannot know what it is. Nor will you come to know which was better or worse after you play. Some people would agonize about which to pick-suspecting there is a best game and fretting about which it is. Others (and I confess myself to be in this group) would pick one, roll the dice, and move on, not worrying about what they cannot know or change. 


\section{Conclusion}

I have argued that deontologists have the tools to deny that constitutive moral luck exists. If it did exist, some constitutional traits would have to be more conducive to improving one's moral standing than others. However, I argued there is reason to think no constitutional trait can have a net expected effect on one's moral standing. Traits that incline one away from acting rightly reduce the chance that one will so act, but offer greater gains in terms of moral standing when one does. Traits that incline one toward moral acts increase that chance, but for lower gains. As a fallback position, if the arguments I offer here cannot eliminate the problem of constitutive moral luck, they can at least give us some reason to worry about it less.

Acknowledgments I am indebted to three anonymous Erkenntnis reviewers, whose comments elevated my argument and exemplified the learned and selfless ideals of peer review. For early formative feedback, I also owe thanks to R. Jay Wallace and other participants at a conference hosted by the Einstein Ethics Group and Humboldt University.

Open Access This article is licensed under a Creative Commons Attribution 4.0 International License, which permits use, sharing, adaptation, distribution and reproduction in any medium or format, as long as you give appropriate credit to the original author(s) and the source, provide a link to the Creative Commons licence, and indicate if changes were made. The images or other third party material in this article are included in the article's Creative Commons licence, unless indicated otherwise in a credit line to the material. If material is not included in the article's Creative Commons licence and your intended use is not permitted by statutory regulation or exceeds the permitted use, you will need to obtain permission directly from the copyright holder. To view a copy of this licence, visit http://creativecommons.org/licen ses/by/4.0/.

\section{References}

Andre, J. (1983). Nagel, Williams, and Moral Luck. Analysis, 43, 202-207.

Aristotle, R. (2009). The Nicomachean Ethics. (W.D. Ross \& L. Brown, Trans.). Oxford: Oxford University Press.

Baxley, M. (2010). Kant's theory of virtue: The value of autocracy. Cambridge: Cambridge University Press.

Benson, P. (1987). Moral worth. Philosophical Studies, 51, 365-382.

Crisp, R. (2017). Moral luck and equality of moral opportunity. Aristotelian Society Supplementary, $91,1-20$.

Dancy, J. (2000). Mill's puzzling footnote. Utilitas, 12, 219-222.

Domsky, D. (2004). There is no door: Finally solving the problem of moral luck. The Journal of Philosophy, 101, 445-464.

Enoch, D., \& Marmor, A. (2007). The case against moral luck. Law and Philosophy, 26, 405-436.

Feinberg, J. (1986). Harm to self. Oxford: Offord University Press.

Fischer, J. (2006). The cards that are dealt you. The Journal of Ethics, 10, 107-129.

Frierson, P. (2017). Denkungsart in Kant's anthropology from a pragmatic point of view. In M. Altman (Ed.), The Palgrave Kant handbook, 643-664. London: Palgrave Macmillan.

Hartman, R. (2017). In defense of moral luck: Why luck often affects praiseworthiness and blameworthiness. New York: Routledge.

Hartman, R. (2019). Moral luck and the unfairness of morality. Philosophical Studies, 176, 3179-3197.

Henson, R. (1979). What Kant might have said: Moral worth and the overdetermination of dutiful action. The Philosophical Review, 88, 39-54. 
Herman, B. (1981). On the value of acting from the motive of duty. The Philosophical Review, 90, $359-382$.

Hurley, S. (1993). Justice without constitutive luck. Royal Institute of Philosophy Supplement, 35, $179-212$.

Kant, I. (1997). Foundations of the metaphysics of morals (M. Gregor, Trans.). Cambridge: Cambridge University Press.

Latus, A. (2003). Constitutive luck. Metaphilosophy, 34, 460-475.

Leunissen, M. (2017). From natural character to moral virtue in Aristotle. Oxford: Oxford University Press.

Mill, J. S. (1863). On Utilitarianism. London: Parker, Son \& Bourn, West Strand.

Nagel, T. (1976). Moral luck. Proceedings of the Aristotelian Society, 50, 137-151.

Nelkin, D. (2016). Difficulty and degrees of moral praiseworthiness and blameworthiness. Nous, 50, 356-378.

Nussbaum, M. (1986). The fragility of goodness: Luck and ethics in Greek tragedy and philosophy. Cambridge: Cambridge University Press.

Rescher, N. (1990). Luck. Proceedings of the American Philosophical Association 64, 5-19.

Rescher, N. (1993). Moral luck. In D. Statman (Ed.), Moral luck, 141-166. State University of New York Press.

Rescher, N. (1995). Luck: The brilliant randomness of everyday life. Pittsburgh: Pittsburgh University Press.

Richards, N. (1986). Luck and desert. Mind, 95, 198-209.

Schinkel, A. (2009). The problem of moral luck: An argument against its epistemic reduction. Ethical Theory and Moral Practice, 12, 267-277.

Slote, M. (1992). From morality to virtue. Oxford: Oxford University Press.

Smith, M. (1994). The moral problem. Malden: Blackwell Publishing.

Statman, D. (1997). The time to punish and the problem of moral luck. Journal of Applied Philosophy, 14, 129-135.

Statman, D. (2005). Doors, keys, and moral luck: A reply to Domsky. The Journal of Philosophy, 102, $422-436$.

Stocker, M. (1976). The Schizophrenia of modern ethical theories. The Journal of Philosophy, 73, 453-466.

Strawson, G. (1986). Freedom and belief. Oxford: Oxford University Press.

Strawson, G. (1994). The impossibility of moral responsibility. Philosophical Studies, 75, 5-24.

Thomson, J. (1989). Morality and bad luck. Metaphilosophy, 20, 203-221.

Williams, B. (1976). Moral luck. Proceedings of the Aristotelian Society, 50, 115-135.

Zimmerman, M. (2002). Taking luck seriously. The Journal of Philosophy, 99, 553-576.

Publisher's Note Springer Nature remains neutral with regard to jurisdictional claims in published maps and institutional affiliations. 